\title{
Letter from Sir Roy Fedden to the President, Sir George Gardner
}

Dear Mr. President,

\section{A Reborn Virile Aircraft Industry}

I congratulate the Society on calling the discussion* on the consequences of the Plowden Report, which was held on Thursday 17th February.

I believe this could be a momentous occasion, but we must be realistic and realise this is a "five minutes to midnight" affair. It will either go down in our history as a determined last stand to help save the country and our profession, or else fade out as a useless academic debate which accomplished nothing worthwhile to meet the desperate practical needs of British aeronautics.

I regret to say that $I$ heard nothing during the evening that led me to believe Council are thinking along the lines of such an immediate determined stand. I respectfully submit that their proposal that a permanent long-term planning authority should be set up, though excellent in conception, is useless and only a waste of time while our profession of aeronautical engineering is still hanging on the brink, with no idea of what the very near future may bring forth.

Frustration and vacillation have led to our losing the proud position we held in aeronautics only 20 years ago, as the culmination of a natural progression during which our engineers had led in every field of transport for the past 100 years. Our chief problems during the last decade have arisen from fear, instability, and lack of steadfastness. I believe this state of affairs could be cleared up within three months, and we owe it to our members to be prepared to go to the stake to bring this about.

When the patient has been saved by an emergency operation and is well on the road to recovery-and it would be staggering how quickly this could be brought about by a firm, continuous, though austere, plan-then we could by all means proceed to these new and sound schemes, which would prevent future relapses. However, today they cannot help much, and might merely depress the patient further.

I am convinced the professional bodies have already done enough spade work to produce suggestions for a definite and detailed ten year programme without bias, which might be thought austere by past standards, but which would re-kindle the faith and dedication of purpose which has now all but been lost.

It is no good asking whether it is to be aircraft carriers or bombers. The services will be fighting about this issue for the next ten years, and any new planning authority will find much of its time taken up by taming them. I warrant that the Society knows better than they do, at least until

*A report on the Discussion evening will be published, it is hoped, in the May JourNaL. such time as there is a single dedicated service in being. So, I say let the Society have a go and get out this interim plan within the next few weeks!

This would be the key stone of the arch, but much more is needed. Success depends on a careful balance between technical, production, financial, and commercial considerations, all bound together by leadership based on discipline, unity of purpose, and a warmth of human understanding. It is here that the rest of the problem lies.

While the Society is erecting a key stone to the arch, Council should approach the Prime Minister himself with a request for a session with him. During this, they should demonstrate to him that he should set up a committee himself to complete the plan, and adjudicate on the three other sides of the proposition, apart from the technical. I do not believe the Prime Minister could refuse such a request from our Society, but if he did, Council should picket number 10 Downing Street until he agreed! I am quite serious about this, and should feel honoured to take my turn with the rest of them.

Is there a man of such wisdom and experience that he could co-ordinate this job impartially? I believe there is, and that he is a member of the Society-which could also second from industry, Farnborough and the universities some 12 to 20 good men who could assist him to complete the job within about 2 months, without help from any other new authority.

All this would enable the machine to start up again and be rolling with renewed vigour in a way in which it has been unable to function for the past 15 years. Just imagine how such a determined stand would capture the imagination of the British public, and indeed the public of the whole world which is informed on such matters! What keenness and enthusiasm could quickly be built up from all grades of staff, from the realisation that there was at least one profession in Britain that would stake its all on what was right and true! Even the trade unions might be re-kindled into becoming what they were set up to be, ensuring that a fair day's work was done for a fair day's pay, and doing their utmost all the time for what could still be the best country in the world.

Yours faithfully,

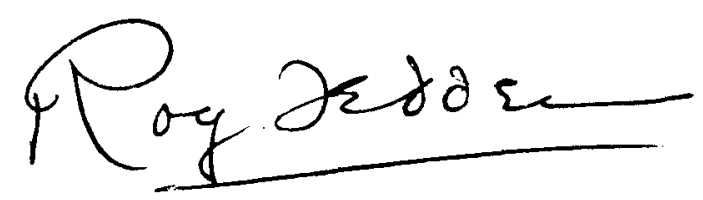

22nd February 1966 